\title{
Wild sorghum from different eco-geographic regions of Kenya display a mixed mating system
}

\author{
Moses M. Muraya • Evans Mutegi • Hartwig H. Geiger · Santie M. de Villiers • \\ Fabrice Sagnard · Ben M. Kanyenji · Dan Kiambi · Heiko K. Parzies
}

Received: 17 November 2010/Accepted: 12 February 2011/Published online: 1 March 2011

(C) Springer-Verlag 2011

\begin{abstract}
Knowledge of mating systems is required in order to understand the genetic composition and evolutionary potential of plant populations. Outcrossing in a population may co-vary with the ecological and historical factors influencing it. However, literature on the outcrossing rate is limited in terms of wild sorghum species coverage and eco-geographic reference. This study investigated the outcrossing rates in wild sorghum populations from
\end{abstract}

Communicated by X. Xia.

Electronic supplementary material The online version of this article (doi:10.1007/s00122-011-1560-5) contains supplementary material, which is available to authorized users.

M. M. Muraya ( $\square)$

Leibniz Institute of Plant Genetics and Crop Plant Research, Corrensstrasse 3, 06466 Gatersleben, Germany

e-mail: mahugu2002@yahoo.com

M. M. Muraya · H. H. Geiger · H. K. Parzies

Institute of Plant Breeding, Seed Science and Population

Genetics, University of Hohenheim, Fruwirthstrasse 21,

70599 Stuttgart, Germany

\section{F. Sagnard}

CIRAD, UMR Développement et Amélioration des Plantes, c/o ILRI, P.O. Box 30709, Nairobi, Kenya

E. Mutegi · S. M. de Villiers · F. Sagnard · D. Kiambi International Crops Research Institute for the Semi-Arid Tropics (ICRISAT-Nairobi), P.O. Box 39063-00623, Nairobi, Kenya

\section{E. Mutegi}

Kenya Agricultural Research Institute (KARI) National

Genebank, P.O. Box 30148-00100, Nairobi, Kenya

B. M. Kanyenji

Kenya Agricultural Research Institute (KARI-Embu),

P.O. Box 27-60100, Embu, Kenya different ecological conditions of Kenya. Twelve wild sorghum populations were collected in four sorghum growing regions. Twenty-four individuals per population were genotyped using six polymorphic simple sequence repeat (SSR) markers to compute their indirect equilibrium estimates of outcrossing rate as well as population structure. In addition, the 12 populations were planted in a field in a randomised block design with five replications. Their progeny (250 individuals per population) were genotyped with the six SSR markers to estimate multi-locus outcrossing rates. Equilibrium estimates of outcrossing rates ranged from 7.0 to $75.0 \%$, while multi-locus outcrossing rates $\left(t_{\mathrm{m}}\right)$ ranged from 8.9 to $70.0 \%$ with a mean of $49.7 \%$, indicating that wild sorghum exhibits a mixed mating system. The wide range of estimated outcrossing rates in wild sorghum populations indicate that environmental conditions may exist under which fitness is favoured by outcrossing and others under which selfing is more advantageous. The genetic structure of the populations studied is concordant with that expected for a species displaying mixed mating system.

\section{Introduction}

Flowering plants exhibit a diversity of mating systems, ranging from complete selfing through cleistogamy to obligatory outcrossing through dioecy (Leblanc et al. 1995; Ross-Ibarra et al. 2007). However, the extent to which the observed variation is induced genetically or environmentally is in most of the cases unknown. This is a serious lack of knowledge, given the contrasting effects the mating system may have on the genetic structure, ecological adaptation and the fitness of plant populations (Booy et al. 2000). Outcrossing leads to a high level of heterozygosity 
and, coupled with recombination, constantly generates new potentially adaptive genotypes. Self-pollination, on the other hand, increases the level of homozygosity and may preserve adaptive combinations of both linked and unlinked genes (Allard 1975). The rate of selfing can vary widely among closely related species and even among populations within species (Jain 1976). Therefore, variable outcrossing rates exhibited by a species may reflect a characteristic that has evolved in response to several ecological variables.

As populations become smaller and habitat disturbance increases, there is a trend towards increased inbreeding and greater variation in outcrossing (Coates et al. 2007). Therefore, changes in the mating system can be useful indicators of population genetic processes and provide valuable insight into the consequences of conservation strategies following anthropogenic disturbances (Neel et al. 2001). Indicators include the outcrossing rate, biparental inbreeding, and the correlation of outcrossed paternity. Selfing or biparental inbreeding leads to an increase in the frequency of homozygotes within a population. Subsequent effects may include inbreeding depression and reduced fitness. Moreover, a loss of genetic diversity is expected from genetic drift.

The majority of wild sorghums found in Africa are classified, along with cultivated sorghum, into the species Sorghum bicolor (L.) Moench (De Wet 1978; Doggett 1988). Cultivated sorghum is further classified as S. bicolor spp bicolor (L.) Moench and wild sorghum as S. bicolor spp verticilliflorum (Steud.) De Wet. S. bicolor is considered a predominantly autogamous and hermaphroditic species. Flowering starts with the terminal flowers of a panicle and continues downwards in a fairly regular manner over a period of 6-15 days (Doggett 1988), providing great opportunity for different mating systems under varying environmental conditions. Literature on outcrossing rates of wild sorghum is limited both in terms of species coverage and eco-geographic reference. Outcrossing rates in wild sorghum species ranging from 0 to almost $100 \%$ have been reported. Hogg and Ahlgren (1943) calculated a mean of $7 \%$ natural outcrossing in johnsongrass (S. halepense) in Wisconsin, USA, Garber and Antwood (1945) found $18-77 \%$ outcrossing in sudangrass (Sorghum bicolor subsp. drummondii) in Pennsylvania, USA, and Pedersen et al. (1998) reported $0-100 \%$ outcrossing on individual sudangrass plants in Nebraska, USA.

Wild sorghum is an important gene reservoir for sorghum crop improvement programmes. For example, resistance mechanisms against the parasitic weed Striga, such as low germination stimulant production, germination inhibition, and low haustorial initiation activity have been found in wild sorghum (Rich et al. 2004). Wild sorghum has novel grain starch properties that could be used to improve digestibility of crop-sorghum for intensive livestock production (Dillon et al. 2007). However, due to the ever-increasing anthropogenic changes to agricultural and natural ecosystems as well as loss of natural habitat due to increasing human and livestock population pressure, wild sorghum may be at risk of genetic erosion. There is therefore a need to study the mating system of wild sorghum in order to develop in situ conservation strategies that will maintain its rich genetic diversity.

Estimating the level of outcrossing in wild sorghum has attracted attention in the context of biosafety of genetically engineered sorghum cultivars. Pollen-mediated gene flow can potentially occur between sorghum cultivars and nearby wild sorghum populations. This is especially important if the genetically engineered traits that, if transferred to wild sorghum populations, may lead to invasiveness, evolution of more aggressive weeds, or the most extreme cases the extinction of wild sorghum populations. Since cultivated and wild sorghum populations occurs sympatrically in Africa (Mutegi et al. 2010; Tesso et al. 2008), pollenmediated gene flow belongs to the most important concerns pertaining to the introduction of genetically engineered sorghum cultivars.

The mating system of a plant species can be determined either directly or indirectly. The direct method is based on a multi-locus mating system model, which allows for the progeny of a single maternal individual to be genotyped at each of several loci (Ritland 2002). The indirect method is based on the frequency of heterozygotes in a population assumed to be in inbreeding equilibrium (Brown and Allard 1970). Under this assumption, equilibrium outcrossing rates can be calculated from Wright's inbreeding coefficient. The direct measure refers to a particular year and environment, while the indirect measure reflects the mating behaviour over many proceeding generations. In the present study we applied both the direct and indirect approaches. We analysed 12 wild sorghum populations from four eco-geographically different regions in Kenya using six simple sequence repeat (SSR) markers.

\section{Materials and methods}

\section{Sample collection}

Twelve wild sorghum populations (three populations per region) were collected in four distinct sorghum growing regions in Kenya (Fig. 1; Table 1). At each sampling site, 24 individuals were collected.

Population estimates of outcrossing rates

Outcrossing rates of wild sorghum populations were assessed at the Kiambere research station of the Kenya 
Fig. 1 Four sorghum growing regions in Kenya (encircled) where wild sorghum populations were sampled

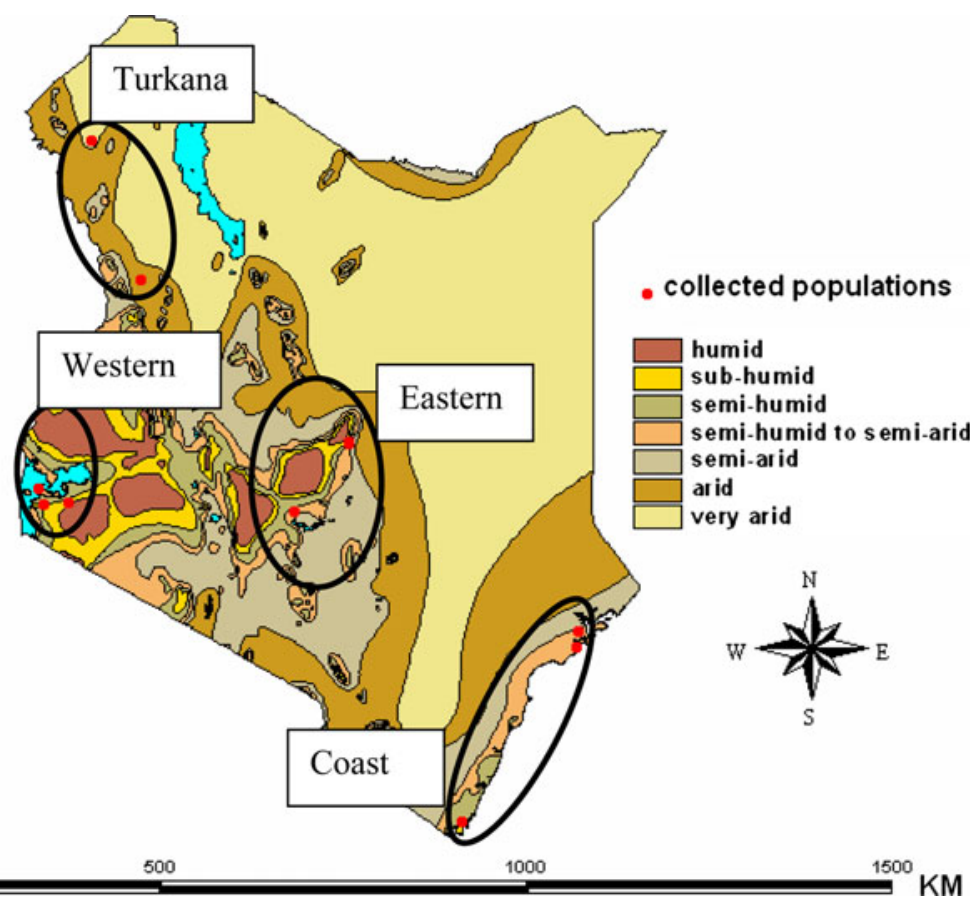

Table 1 Agro-climatic characteristics of the 12 wild sorghum populations sampling sites and of the KARI station chosen for evaluating them

\begin{tabular}{llrlllll}
\hline Population & Region & Alt $(\mathrm{m})$ & AEZ & Classification & Moisture $(\%)$ & Rain $(\mathrm{mm})$ & Temp $\left({ }^{\circ} \mathrm{C}\right)$ \\
\hline T3 & Turkana & 570 & VII & Very arid & $<15$ & $150-350$ & $22-40$ \\
T4 & Turkana & 568 & VII & Very arid & $15-25$ & $150-350$ & $300-550$ \\
T10 & Turkana & 706 & VI & Arid & $65-80$ & $1,200-1,600$ \\
W17 & Western & 1,479 & II & Sub-humid & $50-65$ & $800-1,200$ \\
W26 & Western & 1,143 & III & Semi-humid & $50-65$ & $800-1,200$ \\
W107 & Western & 964 & III & Semi-humid & $22-40$ & $20-35$ \\
C13 & Coast & 3 & IV & Semi-humid to semi-arid & $40-50$ & $>500$ \\
C32 & Coast & 11 & IV & Semi-humid to semi-arid & $40-50$ & $>500$ \\
C49 & Coast & 19 & II & Sub-humid & $65-80$ & $>500$ \\
E40 & Eastern & 892 & IV & Semi-humid to semi-arid & $40-50$ & $751-1,000$ \\
E6 & Eastern & 869 & IV & Semi-humid to semi-arid & $40-50$ & $751-1,000$ \\
E78 & Eastern & 1,169 & IV & Semi-humid to semi-arid & $40-50$ & $22-40$ \\
All & Kiambere & 848 & IV & Semi-humid to semi-arid & $40-50$ & $22-40$ \\
\hline
\end{tabular}

Source: agro-ecological classification and data were obtained from the Ministry of Agriculture (MOA), Kenya

Alt, altitude; AEZ, agro-ecological zone; Rain, annual rainfall range; Temp, growing season temperature range; All, all 12 populations evaluated at the same location (KARI field station at Kiambere, located in Eastern Region)

Agricultural Research Institute (KARI), during the shortrain season of 2007/2008. The 12 wild sorghum populations collected were planted in the field. A randomised complete block (RCBD) design with five replicates and one-row plots was used. Each plot consisted of 30 plants with a spacing of $75 \mathrm{~cm}$ between rows and $50 \mathrm{~cm}$ between plants within rows. At maturity, five plants per plot were randomly selected and harvested. Thus each population consisted of 25 individual plants (panicle). Seeds harvested from the same panicle constituted a family.

\section{DNA extraction and genotyping}

A single seed from each of 24 individuals per collected population was planted in a greenhouse at the University of Hohenheim. In addition, a random sample of ten seeds per harvested panicle (progeny of the original wild sorghum populations) that were grown at Kiambere was also planted. Thus each population consisted of 250 individual plants (25 families, each with 10 progenies). A special protocol was followed for germination in order to overcome physiological 
dormancy in wild sorghum (Muraya and Parzies 2009, unpublished data). Seeds were deglumed and placed in Eppendorf tubes arranged in a rack and warm water $\left(37^{\circ} \mathrm{C}\right)$ was added to each tube. The rack was subsequently incubated overnight $(12 \mathrm{~h})$ in the dark in a water bath at $37^{\circ} \mathrm{C}$. The seeds were placed individually in pots in compost in a greenhouse. Total genomic DNA was extracted from tissues of $5 \mathrm{~cm}$ young lyophylized leaves using a modified CTAB protocol (Mace et al. 2003). Concentration and quality of the DNA was assessed using electrophoresis of $1 \mu \mathrm{l}$ of extracted DNA on a $0.7 \%(\mathrm{w} / \mathrm{v})$ agarose gel followed by normalisation of the concentration at $50 \mathrm{ng} / \mu \mathrm{l}$.

\section{SSR selection}

The SSR markers used in this study were part of 18 generation challenge project markers (Brown et al. 1996; Taramino et al. 1997; Kong et al. 2000; Schloss et al. 2002; AgropolisCIRAD-Genoplante unpublished) previously used to genotype 62 wild sorghum populations (Muraya et al., submitted). The six SSR markers worked efficiently and had the highest polymorphism. Furthermore, we compared the equilibrium outcrossing rate of the 62 populations based on the 6 SSR markers to that of the entire set of 18 SSR markers and found no significant differences (Table S2; PROC TTEST; $P=0.3471)$. We therefore considered the six SSR markers sufficient in estimating the outcrosssing rates of the wild sorghum populations. This is especially because the approach used to estimate outcrossing in this study has been shown to be particularly useful in cases where effort in scoring more loci is less than the effort in scoring more progeny (Ritland 2002; Ritland and Jain 1981). Ritland (2002) showed that six loci could provide accurate estimates of multi-locus mating system as demonstrated by low levels of variance. He demonstrated higher level of accuracy for loci with four alleles compared to those with only two. We expect the SSR markers used in this study to be more informative given that between 19 and 28 alleles per loci were observed (Table S1).

\section{SSR analysis}

A set of six highly polymorphic sorghum SSR markers (Table S1) was used to genotype the extracted genomic DNA. PCR reactions were performed in $10 \mu \mathrm{l}$ reaction volume, containing $1 \times$ PCR buffer $[20 \mathrm{mM}$ Tris $-\mathrm{HCl}(\mathrm{pH}$ 8.4), $50 \mathrm{mM} \mathrm{KCl}$, $1.5 \mathrm{mM} \mathrm{MgCl}_{2}, 0.25 \mu \mathrm{M}$ of each fluorescent labelled forward and unlabelled reverse primers, $0.2 \mathrm{mM}$ dNTPs, 0.5 unit per reaction of Taq polymerase and $100 \mathrm{ng}$ template DNA $(2 \mu \mathrm{l})$. The amplification reaction consisted of a denaturing step of $3 \mathrm{~min}$ at $94^{\circ} \mathrm{C}$, followed by 40 cycles beginning with $94^{\circ} \mathrm{C}$ for $1 \mathrm{~min}$, annealing reaction of $1 \mathrm{~min}$ at $55^{\circ} \mathrm{C}$, extension at $72^{\circ} \mathrm{C}$ for $1 \mathrm{~min}$ followed by one terminal step at $72^{\circ} \mathrm{C}$ for $10 \mathrm{~min}$ and consecutive storage of amplification products at $4^{\circ} \mathrm{C}$. All PCR reactions were performed on a MJ Research icl PTC-100 thermocycler followed by fragment analysis on automated laser fluorescence sequencer (MegaBACE). The genotype "BTX 623" was included as a control on each sample plate to correct for any shift in allele calling.

Estimation of equilibrium outcrossing rates

Twenty-four individuals per population were used to compute estimates of equilibrium outcrossing rate $\left(t_{\mathrm{e}}\right)$ as follows:

$t_{\mathrm{e}}=\frac{1-F}{1+F}$

where $F$ is the inbreeding coefficient which was computed as in Weir (1996). Correlation between $t_{\mathrm{e}}$ and panicle compactness and shape was also computed.

Estimation of multi-locus and average single-locus outcrossing rates

The multi-locus outcrossing rate $\left(t_{\mathrm{m}}\right)$ and the average singlelocus outcrossing rate $\left(t_{\mathrm{s}}\right)$ were estimated using the procedure of Ritland (1986) implemented in the MLTR software 3.0 (Ritland 2002). Calculations were based on a mixed mating model assuming a selfing rate of $s$ and an outcrossing rate of $1-s$. Standard errors (SE) of the estimated outcrossing rates were obtained using 1,000 bootstraps by resampling families within populations. The biparental inbreeding $\left(t_{\mathrm{m}}-t_{\mathrm{s}}\right)$, a measure of mating between relatives, was computed as well as the correlation of paternity $\left(r_{\mathrm{p}}\right)$, i.e., the proportion of full sibs in the outcrossed seeds (Ritland 1989). A multiple test of differences between populations $t_{\mathrm{m}}$ and $t_{\mathrm{s}}$ was performed using SAS version 9.1 (SAS Institute 2004). A significance level of $5 \%$ was used.

\section{Population structure}

To explore differentiation among populations and regions, $F$-statistics parameters $\left(F_{\mathrm{IS}}, F_{\mathrm{IT}}\right.$ and $\left.F_{\mathrm{ST}}\right)$ were estimated in Genetix 4.05 (Belkhir et al. 2004). Cluster analysis of the population was based on Euclidean distances implemented in MEGA versus 4.0 (Tamura et al. 2006). A consensus neighbour joining $(\mathrm{NJ})$ tree was constructed by performing 100 bootstrap replicates.

\section{Results}

Polymorphism of SSR markers

All SSR markers scored were highly polymorphic (Table S1). The number of alleles per marker obtained across all 
12 populations ranged from 19 to 27 and from 18 to 25 for their progenies planted at Kiambere. All the populations displayed high PIC values, ranging from 0.80 to 0.92 in the collected populations and 0.69 to 0.90 in their progenies.

Estimation of equilibrium outcrossing rates

The average number of alleles per SSR marker ranged among populations from 2 to 9 (Table 2). Observed heterozygosity values $(0.03-0.49)$ were lower than the expected heterozygosity values $(0.24-0.78)$, and inbreeding coefficients ranged from 0.14 to 0.86 . The equilibrium estimates of the outcrossing rate varied from 0.07 to 0.75 . The correlation coefficient between $t_{\mathrm{e}}$ and panicle compactness and shape was not significant ( $r=-0.05 ; P=0.88)$.

Estimation of multi-locus and average single-locus outcrossing rates

The $t_{\mathrm{s}}$ and $t_{\mathrm{m}}$ estimates differed significantly between populations ( $P=0.05$; Table 2 ). The $t_{\mathrm{s}}$ values ranged from 0.08 to 0.64 and $t_{\mathrm{m}}$ from 0.09 to 0.70 . On average $t_{\mathrm{s}}$ and $t_{\mathrm{m}}$ estimates were highest in Coast populations. Eastern region had the lowest $t_{\mathrm{s}}$ and $t_{\mathrm{m}}$ values but showed the highest variation between populations. The overall mean $t_{\mathrm{s}}$ and $t_{\mathrm{m}}$ values across all populations were 0.45 and 0.49 , respectively. The overall biparental inbreeding $\left(t_{\mathrm{m}}-t_{\mathrm{s}}\right)$ mean was low for all populations studied. The standard errors of the estimated outcrossing rates were not significantly different from zero. Very low values of the correlation of paternity $r_{\mathrm{p}}$ were found in all the populations, ranging from 0.05 to 0.20 (Table 2), i.e., only $5-20 \%$ of the outcrossed sibs were full sibs.

Comparison of outcrossing rates of the collected wild sorghum populations and their progeny grown in the field at Kiambere (Fig. 2) showed no consistent outcrossing trend among populations originating from same regions. However, on average Coast and Eastern populations showed increased outcrossing rates in their progeny as compared to progeny of Turkana and Western populations, which showed decreased values. Population E40 had lower than $10 \%$ outcrossing rates under both estimates.

Population structure

The estimates of $F_{\mathrm{IS}}, F_{\mathrm{IT}}$ and $F_{\mathrm{ST}}$ were significant at $(P<0.001)$ at both population $(0.42,0.70$ and 0.48 , respectively) and region ( $0.63,0.70$ and 0.20 , respectively). Cluster analysis based on Euclidean distances estimated from the SSR data revealed that sorghum populations were not strictly clustering to their regions of origin (Fig. 3).

\section{Discussion}

Our study revealed great differences in the mating systems of wild sorghum populations. We found multi-locus

Table 2 Diversity statistics, estimated multi-locus and average single-locus outcrossing rates $\left(t_{\mathrm{m}}\right.$ and $\left.t_{\mathrm{s}}\right)$, and multi-locus correlation of paternity $\left(r_{\mathrm{p}}\right)$ of the 12 Kenyan wild sorghum populations from four eco-geographic regions based on six SSR loci

\begin{tabular}{|c|c|c|c|c|c|c|c|c|c|c|c|}
\hline \multirow[t]{2}{*}{ Population } & \multirow[t]{2}{*}{ Region } & \multicolumn{6}{|c|}{ Collected population } & \multicolumn{4}{|c|}{ Progeny planted in field } \\
\hline & & $A_{\mathrm{o}}$ & $H_{\mathrm{e}}$ & $H_{\mathrm{o}}$ & $F$ & $t_{\mathrm{e}}$ & PCS & $t_{\mathrm{s}}(\mathrm{SE})$ & $t_{\mathrm{m}}(\mathrm{SE})$ & $t_{\mathrm{m}}-t_{s}(\mathrm{SE})$ & $r_{\mathrm{p}}(\mathrm{SE})$ \\
\hline $\mathrm{C} 13$ & Coast & 2 & 0.29 & 0.19 & 0.36 & 0.47 & 1 & $0.520 \mathrm{~b}(0.018)$ & $0.574 b(0.02)$ & $0.054(0.003)$ & $0.200(0.000)$ \\
\hline $\mathrm{C} 32$ & Coast & 6 & 0.42 & 0.27 & 0.37 & 0.46 & 5 & $0.500 \mathrm{~b}(0.0000)$ & $0.554 \mathrm{~b}(0.007)$ & $0.054(0.007)$ & $0.053(0.077)$ \\
\hline C49 & Coast & - & - & - & - & - & 1 & $0.600 \mathrm{ab}(0.029)$ & $0.656 \mathrm{ab}(0.03)$ & $0.056(0.002)$ & $0.136(0.200)$ \\
\hline E6 & Eastern & 9 & 0.78 & 0.27 & 0.66 & 0.20 & 2 & $0.540 \mathrm{~b}(0.0220)$ & $0.592 b(0.023)$ & $0.052(0.001)$ & $0.200(0.000)$ \\
\hline $\mathrm{E} 40$ & Eastern & 3 & 0.24 & 0.03 & 0.86 & 0.07 & 2 & $0.082 \mathrm{~d}(0.0420)$ & $0.089 \mathrm{~d}(0.045)$ & $0.007(0.004)$ & $0.057(0.067)$ \\
\hline E78 & Eastern & 8 & 0.64 & 0.30 & 0.55 & 0.29 & 6 & $0.540 \mathrm{~b}(0.0240)$ & $0.594 b(0.022)$ & $0.054(0.002)$ & $0.200(0.000)$ \\
\hline $\mathrm{T} 4$ & Turkana & 4 & 0.38 & 0.15 & 0.63 & 0.23 & 2 & $0.355 \mathrm{c}(0.0250)$ & $0.402 \mathrm{c}(0.030)$ & $0.047(0.005)$ & $0.200(0.011)$ \\
\hline $\mathrm{T} 3$ & Turkana & 4 & 0.53 & 0.46 & 0.15 & 0.73 & 2 & $0.560 \mathrm{~b}(0.0380)$ & $0.618 b(0.041)$ & $0.058(0.013)$ & $0.200(0.000)$ \\
\hline $\mathrm{T} 10$ & Turkana & 2 & 0.26 & 0.21 & 0.21 & 0.65 & 2 & $0.510 \mathrm{~b}(0.0270)$ & $0.570 \mathrm{~b}(0.032)$ & $0.060(0.006)$ & $0.064(0.102)$ \\
\hline W26 & Western & 7 & 0.61 & 0.49 & 0.22 & 0.65 & 6 & $0.388 \mathrm{c}(0.0430)$ & $0.437 \mathrm{c}(0.046)$ & $0.049(0.016)$ & $0.200(0.000)$ \\
\hline W107 & Western & 4 & 0.46 & 0.34 & 0.28 & 0.56 & 2 & $0.600 \mathrm{ab}(0.024)$ & $0.592 b(0.024)$ & $-0.008(0.013)$ & $0.200(0.003)$ \\
\hline W17 & Western & 4 & 0.45 & 0.40 & 0.14 & 0.75 & 1 & $0.640 \mathrm{a}(0.0380)$ & $0.700 \mathrm{a}(0.043)$ & $0.060(0.006)$ & $0.200(0.000)$ \\
\hline Mean & & 4.82 & 0.46 & 0.28 & 0.40 & 0.46 & 4.82 & $0.454(0.02200)$ & $0.497(0.0220)$ & $0.043(0.009)$ & $0.114(0.040)$ \\
\hline
\end{tabular}

Means followed by the same letter are not significantly different from each other at $P=0.05$

Region, region in Kenya which the populations were sampled; $A_{\mathrm{o}}$, average number of alleles per population; $H_{\mathrm{e}}$, expected heterozygosity; $H_{\mathrm{o}}$, observed heterozygosity; $F$, inbreeding coefficient; $t_{\mathrm{e}}$, equilibrium outcrossing rate; PCS, panicle compactness and shape (where $1=$ very lax panicle; $2=$ panicle with very loose erect primary branches; $5=$ panicle with loose drooping primary branches; and $6=$ panicle with semiloose erect primary branches); $t_{\mathrm{s}}$, single-locus outcrossing rate; $t_{\mathrm{m}}$, multi-locus outcrossing rate; $r_{\mathrm{p}}$, multi-locus correlation of paternity and variance estimate were based upon 1,000 bootstraps and units of resampling was family within population 


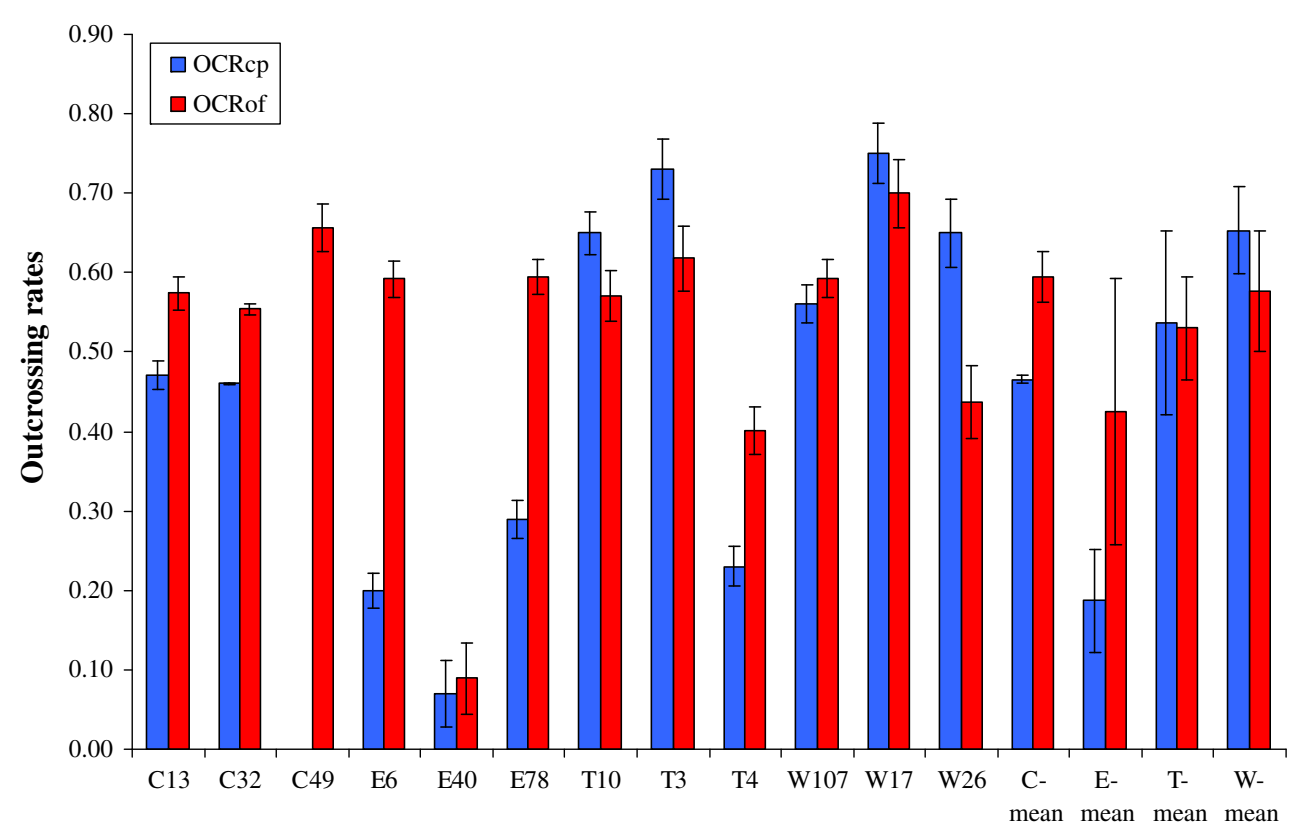

Wild sorghum populations

Fig. 2 Estimates of the outcrossing rates of the 12 wild sorghum populations (OCR $c$ ) collected in four regions of Kenya and their progenies (OCRof) planted in the field at KARI-Kiambere during the 2007/2008 growing season $(C, E, T$ and $W$ series are populations

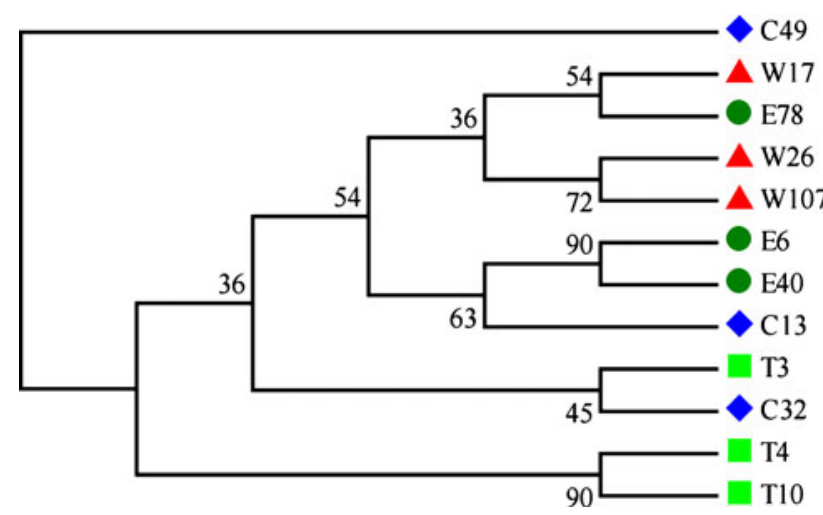

Fig. 3 Neighbour-joining (NJ) consensus tree based on Euclidean distances on allelic data from 6 SSR loci among 12 wild sorghum populations collected from four regions of Kenya. Populations are identified by number and each region is identified by a different symbol and colour. The numbers at the nodes represent the number of times each node was represented in a bootstrap analysis

outcrossing rates ranging from 8.9 to $70 \%$. Equilibrium estimates of outcrosssing rates confirmed the results obtained by Ritland's multi-locus approach. The outcrossing rates were considerably higher than those reported for cultivated sorghum. For example, Dje' et al. (2004) reported outcrossing rates in cultivated sorghum in Morocco of $7-16 \%$, whereas Barnaud et al. (2008) reported 5-40\% for sorghum landraces in Cameroon. Ellstrand and Foster (1983) and Ollitrault et al. (1997) reported an collected at Coast, Eastern, Turkana and Western region, respectively, while mean is the average across the populations). Bars represent the standard errors

average outcrossing rate of cultivated sorghum of 34 and $19 \%$ in USA and Burkina-Faso, respectively. In Kenya, Rabbi et al. (2010) reported outcrossing rates of 5-7\% have been reported in cultivated Ochuti sorghum. Thus our study is in agreement with phylogenetic analyses suggesting that outcrossing systems are ancestral (Schoen et al. 1997; Goodwillie 1999; Vallejo-Marin and Uyenoyama 2004; Porcher and Lande 2005).

Outcrossing rates are influenced not only by the maternal genotype but also by environmental conditions. In our study, variation among wild sorghum populations occurred within a single season (progenies planted at KARIKiambere), in which all plants experienced similar environmental conditions, demonstrating the great outcrossing potential existing in wild sorghum. In the current study, no consistent pattern of outcrossing rate was observed among the agro-ecological zones. Lack of a clearly distinct classification of the populations may bias inferences regarding associations between mating system and ecological trends. In our study we did not identify the species or races of the population studied. However, cluster analysis (Fig. 3) indicate that at least two different populations were found in the same region. Muraya et al. (2010) also showed that at least three species of wild sorghum exist in Kenya and three races of the species S. bicolor spp verticilliflorum. Morever, they revealed that that two or more species of wild sorghum can be found in the same region. These issues notwithstanding, our results indicate that mixed 
mating systems occur frequently in a wide range of wild sorghum populations, motivating continued exploration of the factors that promote their evolutionary stability.

The estimated wide range of outcrossing rates in wild sorghum populations studied indicated that environmental conditions may have existed under which fitness was favoured by outcrossing and others under which selfing was more advantageous. However, the available climatic data for different agro-ecological zones was too variable to deduce any correlation between the outcrossing rates and specific environmental factors. Populations from Eastern region showed the highest variation between populations within the same region. Sites in the Eastern region may considerably differ in altitude (steep fall in altitudinal gradient over short distances) leading to a wide spectrum of climatic conditions which may explain the high variation observed in the outcrossing rates. Abdel-Ghani et al. (2004) showed that outcrossing rates of cultivated and wild barley varied greatly among genotypes and seasons. Comparison of the estimates of equilibrium outcrossing rates between the collected wild sorghum populations and their progenies grown at one location (Fig. 2) indicated that environmental conditions could cause considerable temporal variation in mating behaviour. Low temperatures and light intensity have been found to modify outcrossing in selfing species (Demotes-Mainard et al. 1995; Li et al. 1996). Therefore, studies over successive years are required to measure temporal variation in outcrossing rates of the studied populations.

Beside variation in outcrossing, another important aspect of the mating system is the extent to which mating between relatives contributes to the genetic structure. Estimates of the degree of relatedness between paternal and maternal parents are often missing in studies of mating systems in plants. We observed low biparental inbreeding (overall mean of $4.3 \%$ ), which fits with values obtained for other species (Jarne and Auld 2006). Estimates of biparental inbreeding allow us to differentiate between selffertilisation and mating between relatives. If mating had occurred between relatives such outcrossing events could be blurred.

Mixed mating can result from three types of reproductive systems (Cruden and Lyon 1989). First, a genetically based selfing rate polymorphism can exist, for example in populations that contain both self-compatible and selfincompatible individuals (Stone 2002). This was not supported in this study since no significant differences were observed in outcrossing rates between families (progenies of individual plants) within a population. Second, species can exhibit heteromorphic flowering systems (Schoen and Lloyd 1984; Masuda et al. 2004), such as cleistogamous (purely selfing) and chasmogamous flowers (both outcrossing and selfing possible). Thirdly, all flowers are chasmogamous, and progenies may arise from selfing, outcrossing or a mixture of both (Schoen and Brown 1991). Wild sorghum populations in Kenya likely display the second or third type of reproductive system. Cultivated sorghum has considerably lower outcrossing rates (Dje et al. 2004; Barnaud et al. 2008; Rabbi et al. 2010) and might have more cleistogamous flowers than wild sorghum. Plants that have both chasmogamous and cleistogamous flowers display high levels of reproductive assurance, because under selfing natural selection reduces inbreeding depression by purge deleterious recessive alleles (Keller and Waller 2002; Weekley and Brothers 2006). Under a mixed mating system displayed by Kenyan wild sorghum, it would be expected that selfing will produce seeds under resource-limited conditions thus ensuring reproduction while outcrossing reduce inbreeding depression causing additional genetic variation when conditions are favourable.

Panicle shape has been considered to play a major role in determining outcrossing rate in cultivated sorghum Dje' et al. (2004) suggested that genotypes with loose panicles display higher outcrossing than those with compact panicles. Our study did not agree with this, as there was no correlation between outcrossing and panicle compactness and shape. Results of this study rather suggest that outcrossing is largely influenced by ecological conditions rather than panicle morphology. Populations with same panicle compactness and shape but originating from ecologically different sites displayed different outcrossing rates.

Cultivation of sorghum in Kenya carries a risk of introgressing genes, including transgene into wild sorghum populations, as wild sorghum occurs abundantly in or near farmers' fields and most genotypes are cross-compatible with cultivated sorghum. Till-Bottraud et al. (1992) showed that even foxtail millet, a largely self-pollinated species, may exchange genetic information with wild relatives at a rate that may cause problems if transgenic cultivars are grown in proximity. Although flowering phenology in sorghum reduces pollen-mediated gene flow, it does not fully prevent pollen exchange unless no overlap in flowering time exists between wild and cultivated sorghum.

Acknowledgments This study was funded by the United States Agency for International Development (USAID) Biotechnology and Biodversity Interface Program (BBI; Dr. Fabrice Sagnard), the Institute of plant Breeding and Population Genetics at the University of Hohenheim, Germany, and Germany Academic Exchange Service (DAAD: A0523923). USAID-BBI funded field experiments and collection trips. University of Hohenheim, Institute of plant Breeding Seed Science, and Population Genetics, Germany, provided laboratory infrastructure and consumables for genotyping work. We are grateful to Kenya Agricultural Research Institute and Ben Kanyenji who supervised the collection of genetic materials [in full compliance 
with regulations according to the Convention on Biological Diversity (CBD)], planting and data collection in the field (KARI-Kiambere).

\section{References}

Abdel-Ghani AH, Parzies HK, Omary A, Geiger HH (2004) Estimating the out crossing rate of barley landraces and wild barley population collected from ecologically different regions of Jordan. Theor Appl Genet 109:588-595

Allard RW (1975) The mating system and microevolution. Genetics 79:115-126

Barnaud A, Trigueros G, McKey D, Joly HI (2008) High outcrossing rates in fields with mixed sorghum landraces: how are landraces maintained? Heredity 101:445-452

Belkhir K, Borsa P, Chikhi L, Raufaste N, Bonhomme F (2004) Université de Montpellier II; Montpellier, France: 1996-2004. Genetix 4.05, logiciel sous Windows TM pour la génétique des populations. Laboratoire Génome, Populations, Interactions, CNRS UMR 5171

Booy GR, Hendricks JJ, Smulders MJM, Van Groenendael JM, Vosman B (2000) Genetic diversity and the survival of populations. Plant Biol 2:379-395

Brown AHD, Allard RW (1970) Estimation of the mating system in open-pollinated maize populations using isozyme polymorphism. Genetics 66:133-145

Brown SM, Hopkins MS, Mitchell SE, Senior ML, Wang TY, Duncan RR, Gonzales-Candelas F, Kresovich S (1996) Multiple methods for identification of polymorphic simple sequence repeats (SSRs) in sorghum (Sorghum bicolor (L.) Moench). Theor Appl Genet 93:190-198

Coates DJ, Sampson JF, Yates CJ (2007) Plant mating systems and assessing population persistence in fragmented landscapes. Aust J Bot 55:239-249

Cruden RW, Lyon DL (1989) Facultative xenogamy: examination of a mixed mating system. In: Bock JH, Linhart YB (eds) The evolutionary ecology of plants. Westview, Boulder, pp 171-207

De Wet JMJ (1978) Systematics and evolution of Sorghum Sect. Sorghum (Gramineae). Am J Bot 65:477-484

Demotes-Mainard S, Doussinault G, Meynard JM (1995) Effect of low radiation and low temperature at meiosis on pollen viability and grain set in wheat. Agronomie 15:357-365

Dillon SL, Shapter FM, Henry RJ, Cordeiro G, Izquierdo L, Lee LS (2007) Domestication to Crop improvement: genetic resources for Sorghum and Saccharum (Andropogoneae). Ann Bot 100:975-989

Dje' Y, Heuertz M, Ater M, Lefebvre C, Vekemans X (2004) In situ estimation of outcrossing rate in sorghum landraces using microsatellite markers. Euphytica 138:205-212

Doggett H (1988) Sorghum, 2nd edn. Longman, London

Ellstrand NC, Foster KW (1983) Impact of population structure on the apparent outcrossing rate of grain sorghum (Sorghum bicolor). Theor Appl Genet 66:323-327

Garber RJ, Antwood SS (1945) Natural crossing in sudan grass. J Am Soc Agron 37:365-369

Goodwillie C (1999) Multiple origins of self-compatibility in Linanthus section Leptosiphon (Polemoniaceae): phylogenetic evidence from internal-transcribed-spacer sequence data. Evolution 53:1387-1395

Hogg PG, Ahlgren HL (1943) Environmental, breeding, and inheritance studies of hydrocyanic acis in sorghum vulgare var. Susanese. J Agric Res 67:195-210

Jain SK (1976) The evolution of inbreeding in plants. Annu Rev Ecol Syst 7:469-495
Jarne P, Auld JR (2006) Animal mix it up too: the distribution of selffertilization among hermaphroditic animals. Evolution 60:18161824

Keller LF, Waller DM (2002) Inbreeding effects in wild populations. Trends Ecol Evol 17:230-240

Kong L, Dong J, Hart GE (2000) Characteristics, linkage-map positions, and allelic differentiation of Sorghum bicolor (L.) Moench DNA simple-sequence repeats (SSRs). Theor Appl Genet 101:438-448

Leblanc O, Peel MD, Carman JG, Savidan Y (1995) Megasporogenesis and megagametogenesis in several Tripsacum species (Poaceae). Am J Bot 82:57-63

Li HB, Zhang Q, Liu AM, Zou JS, Chen JS (1996) A genetic analysis of low-temperature-sensitive sterility in indica-japonica rice hybrids. Plant Breed 115:305-309

Mace ES, Buhariwalla HK, Crouch JH (2003) A high throughput DNA extraction protocol for molecular breeding programs. Plant Mol Biol Report 21:459a-459h

Masuda M, Yahara T, Maki M (2004) Evolution of floral dimorphism in a cleistogamous annual, Impatiens noli-tangere L. occurring under different environmental conditions. Ecol Res 19:571-580

Muraya MM, Hartwig HH, Mutegi E, Kanyenji BM, Sagnard F, de Villiers S, Kiambi D, Heiko K, Parzies HK (2010) Geographical patterns of phenotypic diversity and structure of Kenyan wild sorghum populations (Sorghum spp) as an aid to germplasm collection and conservation strategy. Plant Genet Resour $8: 217-224$

Mutegi E, Sagnard F, Muraya M, Kanyenji B, Rono B, Mwongera C, Marangu C, Kamau J, Parzies H, de Villiers S, Semagn K, Traoré PS, Labuschagne M (2010) Ecogeographical distribution of wild, weedy and cultivated Sorghum bicolor in Kenya: implications for conservation and crop-to-wild gene flow. Genet Resour Crop Evol 57:243-253

Neel MC, Ross-Ibarra J, Ellstrand NC (2001) Implications of mating patterns for conservation of the endangered plant Eriogonum ovalifolium var. vineum (Polygonaceae). Am J Bot 88:12141222

Ollitrault P, Noyer JL, Chantereau J, Glaszmann JC (1997) Structure génétiques et dynamique des variétés traditionnelles de sorgho au Burkina-Faso. In: Begic A (ed) Gestion des ressources génétiques des plantes en Afrique des savanes. IER-BRG Solagral, Bamako, pp 231-240

Pedersen JF, Toy JJ, Johnson B (1998) Natural outcrossing of sorghum and sundangrass in the central great plains. Crop Sci 38:937-939

Porcher E, Lande R (2005) Loss of gametophytic self-incompatibility with evolution of inbreeding depression. Evolution 59:46-60

Rabbi IY, Parzies HK, Kiambi D, Haussmann BIG, Folkertsma R, Geiger HH (2010) Experimental studies on pollen-mediated gene flow in Sorghum bicolor (L.) Moench using malesterile bait plants. Plant Breeding. doi:10.1111/j.1439-0523.2010.01775.x

Rich PJ, Grenier C, Ejeta G (2004) Striga resistance in the wild relatives of sorghum. Crop Sci 44:2221-2229

Ritland K (1986) Joint maximum likelihood estimation of genetic and mating structure using open-pollinated progenies. Biometrics 42:25-43

Ritland K (1989) Correlated matings in the partial selfer Mimulus guttatus. Evolution 43:848-859

Ritland K (2002) Extension of models for the estimation of mating systems using $\mathrm{n}$ independent loci. Heredity 88:221-228

Ritland K, Jain SK (1981) A model for the estimation of outcrossing rate and gene frequencies using $\mathrm{n}$ independent loci. Heredity 47:35-52

Ross-Ibarra J, Morrell PL, Gaut BS (2007) Plant domestication, a unique opportunity to identify the genetic basis of adaptation. Proc Nat Acad Sci 104:8641-8648 
SAS Institute (2004) The SAS system for windows, version 9.1. The SAS Institute, Cary

Schloss SJ, Mitchell SE, White GM, Kukatla R, Bowers JE, Paterson AH, Kresovich S (2002) Characterization of RFLP probe sequences for gene discovery and SSR development in Sorghum bicolor(L.) Moench. Theor Appl Genet 105:912-920

Schoen DJ, Brown AHD (1991) Whole and partflower self-pollination in Glycine clandestine and G. argyrea and the evolution of autogamy. Evolution 45:1651-1664

Schoen DJ, Lloyd DG (1984) The selection of cleistogamy and heteromorphic diaspores. Biol J Linn Soc 23:303-322

Schoen DJ, Johnston MO, L'Heureux AM, Marsolais JV (1997) Evolutionary history of the mating system in Amsinckia (boraginaceae). Evolution 51:1090-1099

Stone JL (2002) Molecular mechanisms underlying the breakdown of gametophytic selfincompatibility. Q Rev Biol 77:17-32

Tamura K, Dudley J, Nei M, Kumar S (2006) Integrated software for Molecular Evolutionary Genetics Analysis and sequence alignment. Version 4.0 (Beta release) Center for Evolutionary Functional Genomics Bio design Institute, Arizona State University
Taramino G, Tarchini R, Ferrario S, Lee M, Pe“ ME (1997) Characterisation and mapping of simple sequence repeats (SSR) in Sorghum bicolor. Theor Appl Genet 95:66-72

Tesso T, Kapran I, Grenier C, Snow A, Sweeney P, Pedersen J, Marx D, Bothma G, Ejeta G (2008) The potential for crop-to-wild gene flow in sorghum in Ethiopia and Niger: a geographic survey. Crop Sci 48:1425-1431

Till-Bottraud I, Reboud X, Brabant P, Lefranc M, Rherissi B, Vedel F, Darmency H (1992) Outcrossing and hybridization in wild and cultivated foxtail millets: consequences for the release of transgenic crops. Theor Appl Genet 83:940-946

Vallejo-Marin M, Uyenoyama MK (2004) On the evolutionary costs of self-incompatibility: incomplete reproductive compensation due to pollen limitation. Evolution 58:1924-1935

Weekley CW, Brothers A (2006) Failure of reproductive assurance in the chasmogamous flowers of Polygala lewtonii (Polygalaceae), an endangered sandhill herb. Am J Bot 93:245-253

Weir BS (1996) Genetic data analysis II. Sinauer Associates, Sunderland 